
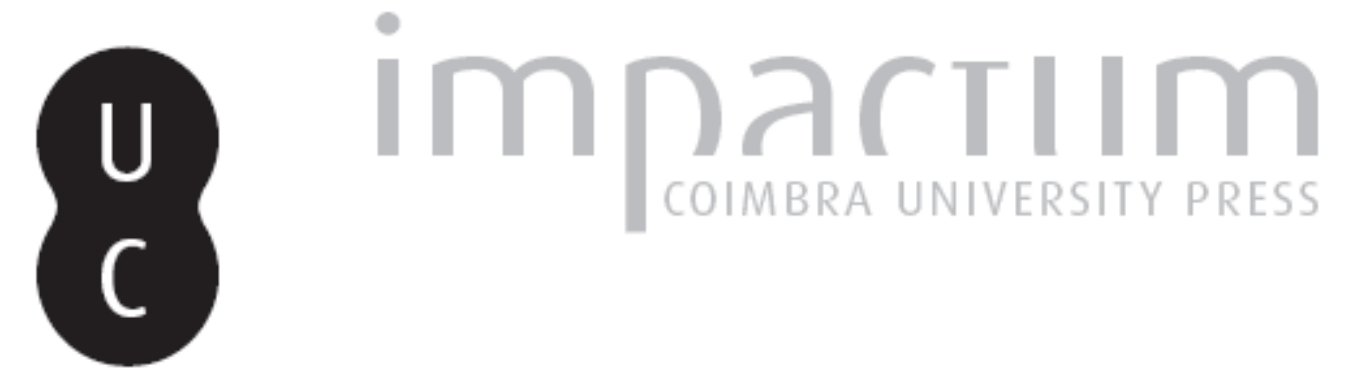

\title{
A maçonaria e a restauração da Carta Constitucional em 1842: o golpe de estado de Costa Cabral
}

\author{
Autor(es): $\quad$ Catroga, Fernando
}

Publicado por: Imprensa da Universidade de Coimbra

URL persistente:

URI:http://hdl.handle.net/10316.2/45073

DOI:

DOI:https://doi.org/10.14195/2183-8925_7-2_4

Accessed : $\quad$ 26-Apr-2023 05:52:03

A navegação consulta e descarregamento dos títulos inseridos nas Bibliotecas Digitais UC Digitalis, UC Pombalina e UC Impactum, pressupõem a aceitação plena e sem reservas dos Termos e Condições de Uso destas Bibliotecas Digitais, disponíveis em https://digitalis.uc.pt/pt-pt/termos.

Conforme exposto nos referidos Termos e Condições de Uso, o descarregamento de títulos de acesso restrito requer uma licença válida de autorização devendo o utilizador aceder ao(s) documento(s) a partir de um endereço de IP da instituição detentora da supramencionada licença.

Ao utilizador é apenas permitido o descarregamento para uso pessoal, pelo que o emprego do(s) título(s) descarregado(s) para outro fim, designadamente comercial, carece de autorização do respetivo autor ou editor da obra.

Na medida em que todas as obras da UC Digitalis se encontram protegidas pelo Código do Direito de Autor e Direitos Conexos e demais legislação aplicável, toda a cópia, parcial ou total, deste documento, nos casos em que é legalmente admitida, deverá conter ou fazer-se acompanhar por este aviso.

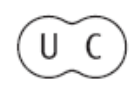




\section{REVISTA DE HISTORIA DAS IDEIAS 7}

\section{REVOLTAS E REVOLUCOẼS}

\section{**}

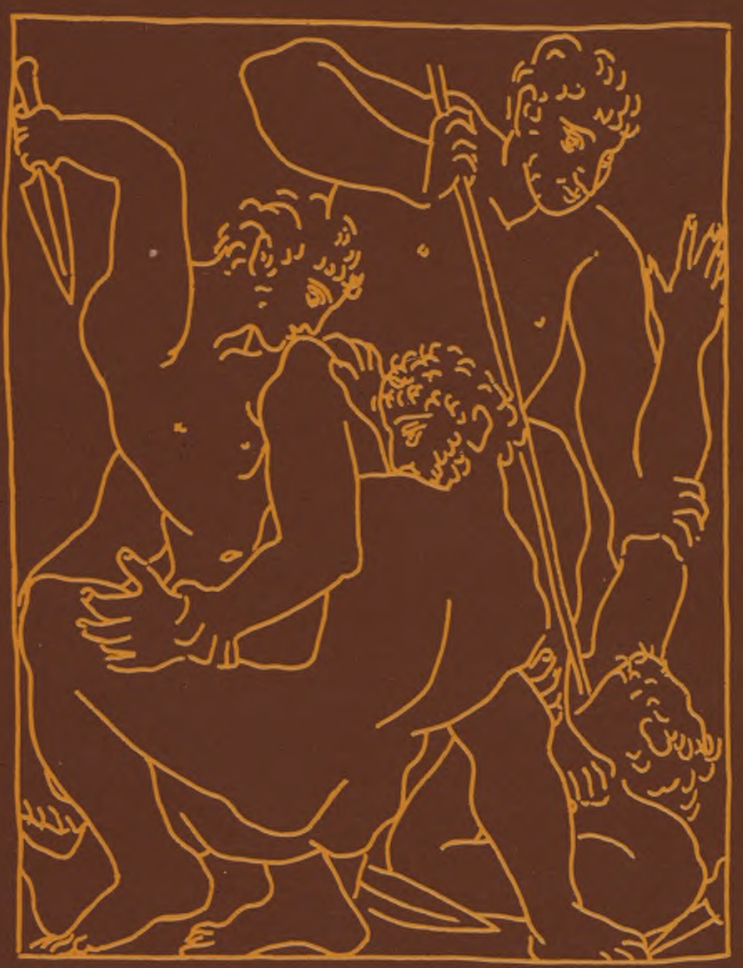

INSTITUTO DE HISTÓRIA E TEORIA DAS IDEIAS FACULDADE DE LETRAS 


\author{
A MAÇONARIA E A RESTAURAÇÃO \\ DA CARTA CONSTITUCIONAL EM 1842
}

O GOLPE DE ESTADO DE COSTA CABRAL

No longo percurso político que levou da liquidação do Absolutismo à República, nenhuma outra organização aparece tão responsabilizada por revoltas, golpes de estado óu revoluções como a maçonaria. Mas se se descer ao campo dos factos e se se indagar a justeza de tais suspeitas, depara-se com uma ausência quase total de equacionamentos objecti vos do problema. Os juízos oscilam entre afirmações apologéticas ou meros anátemas maniqueístas, o que não admira, dada a paixão e o mistério que o problema suscita. A inexistência de uma história da maçonaria para grande parte do período em causa 0) e a circunstância de razões várias impedirem o acesso franco a arquivos essenciais para o seu estudo têm ajudado $\mathrm{a}^{*}$

* Faculdade de Letras da Universidade de Coimbra.

O Com efeito, para os inícios da Arte Real entre nós e sua progressão até à revolução vintista, existe a obra fundamental de Graça e J. S. da Silva Dias, Os Primórdios da Maçonaria em Portugal, 4 vols., Lisboa, I.N.I.C., 1980. Uma síntese utilíssima sobre a evolução da maçonaria no decorrer do século XIX e princípios do século XX encontra-se em A. H. de Oliveira Marques, $A$ Maçonaria Portuguesa e o Estado Novo, Lisboa, D. Quixote, 1975, pp. 15-54. Por outro lado, apesar da óptica parcial com que foi escrita, ainda se lê com proveito o estudo de M. Borges Graínha, História da Franco-Maçonaria em Portugal (1733-1912), Lisboa, A. Editora Limitada, 1912. Análises sobre aspectos concretos têm vindo a lume últimamente e, entre elas, destacamos: Fernando Marques da Costa, $\mathrm{A} \mathrm{Ma}$ çonaria Feminina, Lisboa, Editorial Vega, s. d.; e João José Alves Dias, «A República e a Maçonaria (O Recrutamento Maçónico na eclosão da República Portuguesa)», Nova História, n. ${ }^{\circ}$ 2, Dezembro 1984, pp. 31-73. 


\section{Revoltas e Revoluções}

manter tal situação $\left({ }^{2}\right)$. Daí o escopo deste trabalho: dar um pequeno contributo para a análise das relações entre a maçonaria e a política liberal na fase de arranque e consolidação do novo regime. Com isso, pretender-se-á ilustrar também algo que um primeiro contacto com o tema nos tornou patente: a diversidade e a conflitualidade das várias organizações maçónicas, reflectindo as tendências políticas da sociedade profana, e o seu funcionamento como núcleos aglutinadores de militantismo, actuando, assim, mais como clubes ou proto-partidos do que como sociedades filantrópicas. E o destaque que iremos dar ao processo que desaguou na reacção anti-setembrista e na restauração da Carta pretende mostrar, concretamente, como é que tais divergências, se colocaram algumas maçonarias em uníssono com a esquerda liberal, conduziram o Grande Oriente Lusitano a definir-se como uma força conservadora, apostada, nos momentos de crise, em bloquear os ímpetos revolucionários.

\section{A politização maçónica nos inícios do regime liberal}

Com a vitória liberal em 1834, a maçonaria portuguesa apareceu dividida $\left({ }^{3}\right)$, tendo como pontos de referência algumas das principais figuras da nova situação: José da Silva Carvalho (Hidaspe) (4), Saldanha, e Passos Manuel (Howard). As lojas governadas por Carvalho reivindicaram a herança do velho

C) Realidade que contrasta com investigações universitárias sobre a maçonaria levadas a efeito em outros países, nomeadamente em França e Espanha. Cf. Pierre Chevallier, Histoire de la Franc-Maçonnerie française, 3 vols., Paris, Fayard, 1974; J. A. Ferrer Benimeli, Masonería española contemporánea, 2 vols., Madrid, Siglo XXI, 1980 .

(3) Sobre as divisões maçónicas nos inícios do regime liberal, leiam-se: Miguel António Dias, Architectura Mystica do Rito Francez ou Moderno..., 5843, p. 259, e Annaes e Codigo dos Pedreiros Livres.... Lisboa, 1853, pp. 103 e ss.; M. Borges Grainha, oh. cit. pp. 113-116. Possivelmente a partir de 1839, um negociante espanhol instalou em Lisboa uma loja, que seguia o rito escocês, regularizada pelo Grande Oriente de Dublin. Esta maçonaria, conhecida por Grande Loja Provincial do Oriente Irlandês, funcionou independente, vindo a integrar-se, mais tarde, no G.O.L.U. No entanto, dado que teve uma acção dominantemente filantrópica, não será relevada neste nosso estudo.

(4) Sempre que pudermos e acharmos útil, indicaremos em itálico o nome simbólico dos mações mais importantes. Aliás, o seu estudo não deixará de ser importante para se caracterizar o horizonte ideológico em que se moviam os membros das lojas, tarefa que, logicamente, aqui não pode ser levada a cabo. No entanto, não deixa de ser significativo o peso de referências a figuras da antiguidade clássica, em particular a políticos e a oradores. 


\section{A Maçonaria e a Restauração}

Grande Oriente Lusitano, enquanto as de Saldanha se tinham autonomizado em França, durante a emigração, como consequência de divergências com os elementos mais conservadores dominantemente sediados em Inglaterra. Passos Manuel, que se tinha iniciado ainda no exílio, formou a sua própria maçonaria ao regressar à pátria. Por isso, no início do novo regime, os mações portugueses apareceram organizados em três maçonarias: o Grande Oriente Lusitano, a Maçonaria do Sul (ou de Saldanha) e Maçonaria do Norte (onde pontificavam Passos Manuel e seu irmão José Passos). E se a primeira seguia uma linha pró-britânica e era fiel à Carta, as restantes perfilhavam posições mais à esquerda, combatendo a hegemonia que os «amigos de D. Pedro» - também mação $\left(^{5}\right)$ - alcançaram nos primeiros governos liberais.

Com a vitória sobre as forças miguelistas, pode dizer-se que a contradição principal da política portuguesa começou a deslocar-se do pólo liberalismo-absolutismo para o interior do bloco triunfador em 1834. E a unidade, já difícil de manter durante o exílio e a guerra, tornou-se impossível quando passou a estar em causa a partilha do poder, a ocupação do aparelho de estado, bem como o lançamento da nova ordem económica (indemnizações, empréstimos externos, venda dos bens nacionais). Necessariamente, este choque de interesses tinha de encontrar eco em instituições cuja funcionalidade era, então, de natureza prevalentemente proto-partidária. É que, num sistema que pressupunha a representação política, as maçonarias, a par das forças armadas, surgiam como os únicos núcleos minimamente organizados. A esta luz, não admira que, no decorrer da década de trinta, encontremos a militância maçónica explícita e directamente condicionada por tais divisões: "Os chefes, últimos e actuais da Ord. $I$ - escreveu Miguel António Dias (Gama) - , em lugar de the terem dado uma organização compatível com a sua índole originária, única que pode tornar a Maç.l estável e útil, não têm feito mais do que transformá-la em facções puramente políticas, para se elevarem às honras e aos interesses profanos» $\left({ }^{6}\right)$.

Não surpreende, assim, que esta politização conferisse às oficinas mais um estatuto de clube político $\left.{ }^{7}\right)$ do que de lojas

(5) D. Pedro ter-se-ia iniciado em 1822. A 21 de Setembro daquele ano foi eleito grão-mestre da maçonaria brasileira. Cf. M. Borges Graínha, ob. cit., p. 113. vres, p. 71 .

(6) Miguel António Dias, Annaes e Codigo dos Pedreiros Li-

O Cf. M. Borges Graínha, ob. cit., p. 104. Veja-se também A. M. da Cunha Belém, Le Grand Orient Lusitanien, Lisbonne, Imprimerie Franco-Portugueza, 1869, pp. 25-26. 


\section{Revoltas e Revoluções}

maçónicas, o que se explica se se tiver presente a imaturidade do regime e a quase inexistência de condições mínimas necessárias ao funcionamento do sistema representativo (opinião pública, organização colectiva dos interesses particulares, partidos políticos ou facções organizadas). Por isso, as sociedades secretas tòrnaram-se a tal ponto num instrumento decisivo de combate político que, ainda nos inícios da década de quarenta, um viajante estrangeiro caracterizava os seus elos com o poder nestes termos: «elas têm tão grandes e tão poderosas ligações, tanto pessoais como materiais que proíbem até o pensar na sua abolição. O seu influxo é inegável, a sua propagação universal, e as suas tendências inteiramente diversas da acção filantrópica, e regular de outros sistemas de maçonaria. A tendência das lojas portuguesas é exclusivamente política» $\left.{ }^{8}\right)$. É certo que os clubes $\mathrm{e}$ as associações patrióticas, com fronteiras entre si e as maçonarias bastante fluídas, contribuíram, em certa medida, para o preenchimento daqueles requisitos. Por outro lado, a animação do jornalismo político apontava no mesmo sentido, e existiam igualmente outras instâncias que pressionavam a formação da vontade política: no campo radical, a par das maçonarias respectivas, dos clubes $\left(^{9}\right)$ e da representação parlamentar, haviâ ainda as Guardas Nacionais e o batalhão do Arsenal; no terreno mais conservador, o exército de linha, a Câmara dos Pares e o Parlamento, a Corte e as legações estrangeiras, nomeadamente as embaixadas da Inglaterra e da Bélgica. De qualquer modo, estamos em crer que as lojas foram os agrupamentos que mais se aproximaram da funcionalidade próxima da dos partidos políticos da fase posterior. Assim sendo, o estudo da evolução da maçonaria e das lutas que a atravessaram é uma das condições basilares para se compreender o processo que conduziu à consolidação do sistema representativo.

Com efeito, se é certo que, na continuidade das tradições revolucionárias dos finais de setecentos e princípios do século XIX, os clubes e as associações patrióticas continuaram a

$\left.{ }^{8}\right)$ Príncipe Lichnowsky, Portugal. Recordações do anno de

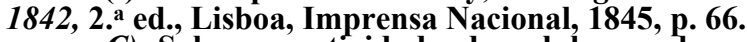

$C)$ Sobre a actividade dos clubes e das associações patrióticas entre 1834 e 1836, vejam-se: $A$. $B$. da Costa Cabral. Apontamentos Historicos, vol. 1, Lisboa, Typographia Silva, 1844, pp. 37-38; José de Arriaga, História da Revolução de Setembro, t. II, Lisboa, Typ. da Companhia Nacional Editora, 1892, pp. 25 e ss.; Marques Gomes, Luctas Caseiras. Portugal de 1834 a 1851, t. I, Lisboa, Imprensa Nacional, 1394, pp. 185 e ss.; Victor de Sá, A Revolução de Setembro de 1836, Lisboa, D. Quixote, 1969, pp. 55 e ss.; Maria Carlos Radich, «Formas de organização política: sociedades patrióticas e clube políticos, 1820-1836", in O Liberalismo na Península Ibérica na primeira metade do século $X I X$, vol. 1, Lisboa, Sá da Costa, 1982, pp. 117-72. 


\section{A Maçonaria e a Restauração}

ter um peso importante, pois actuaram como centros de agitação e de formação da opinião, a maçonaria, quer pela maior duração das suas estruturas, quer pelas relações estreitas com outros centros (clubes, Guardas Nacionais, exército), quer ainda por uma prática interna que fomentava a oratória e postulava na sua governação métodos com alguma democraticidade e disciplina, foi o agrupamento que desempenhou, de um modo mais constante, as tarefas que, com a maturação do sistema, passarão em grande parte para as estruturas politico-partidárias. E isto não admira se se tiver em vista que a luta pela liquidação do Antigo Regime foi longa e violenta, obrigando o processo revolucionário a seguir uma via específica de longa duração (conquanto mais próxima do exemplo francês do que inglês). Em consequência, as formas de sociabilidade política de tipo especificamente partidário só emergiram tardiamente $\left({ }^{10}\right)$ e, mais do que da evolução orgânica de grupos parlamentares, resultaram de um percurso em que o clubismó, as associações patrióticas e as maçonarias, associadas ao caciquismo, tiveram um papel crucial. Por conseguinte, o estudo destas agremiações é, sem sombra de qualquer dúvida, de nuclear importância para a compreensão da génese e evolução dos agrupamentos políticos do Portugal oitocentista; mas, concomitantemente, o relacionamento das lutas sociopolíticas com a história das maçonarias é também condição necessária para se explicar as características orgânicas, as rupturas e as mutações ideológicas por que passaram os vários Orientes desde os alvores do liberalismo até à eclosão do republicanismo e ao estabelecimento da 1. ${ }^{\mathrm{a}}$ República.

\section{A luta inter-maçónica: a revolução de Setembro}

Comecemos pela análise, ainda que sintética, do itinerário do Grande Oriente Lusitano na segunda metade da década de trinta. Como vimos, esta maçonaria considerava-se a única regular e, do ponto de vista político-ideológico, posicionava-se na ala moderada do liberalismo português. E não será precipitado afirmar-se que exerceu uma grande influência na governação do país, sobretudo a partir do momento em que os seus mais altos dignatários — Silva Carvalho (grão-mestre) e Agostinho

(10) Sintoma deste estado de coisas é o facto de só na década de quarenta ter ganho corpo a ideia de programa político. Cf. Jorge Borges de Macedo, O aparecimento em Portugal do conceito de programa político, Separata da Revista Portuguesa de História, Coimbra, 1971. 


\section{Revoltas e Revoluções}

José Freire (grande-administrador) - passaram a ser figuras dominantes junto de D. Pedro ( $\left.{ }^{\mathrm{n}}\right)$. E existem testemunhos que indicam que as lojas serviram de veículo para a conquista do novo aparelho de estado, mesmo quando ainda não estava terminada a guerra civil. Pelo menos essa é a acusação que José Liberato Freire de Carvalho deixou exarada nas suas Memórias: ainda no Porto, os «amigos de D. Pedro» ter-se-ão rodeado de um grande «exército auxiliar dos chamados empregados públicos» e cujo número terá chegado «a novecentos» ${ }^{12}$, e de um «antigo instrumento de que alguns dos actuais ministros já se tinham servido nos anos de 1822 e 23, também agora se procuraram servir; e este foi a criação de lojas maçónicas, receptáculo da criadagem ministrial mais servil que havia no Porto» $\left({ }^{13}\right)$.

Logicamente, a vocação situacionista do Grande Oriente Lusitano tinha de o colocar na mira dos ataques da Maçonaria do Norte e da Maçonaria do Sul, do mesmo modo que, a nível político, a esquerda criticava a orientação dos primeiros governos liberais a partir de princípios mais radicais. Em suma: contestava-se o modelo alto-burguês que se pretendia instaurar e apelava-se para uma morigeração que o clientelismo tinha posto em causa. Nesta perspectiva, não espanta que, com a revolução de Setembro, se tenha gerado um clima de instabilidade maçónica só compreensível desde que equacionado à luz da luta entre as facções liberais que ainda não tinham encontrado a base consensual adequada à alternância do poder.

Não é este lugar para nos pronunciarmos sobre o significado da revolução de Setembro de $1836{ }^{(14)}$. Porém, parecemos incontroverso que o movimento revolucionário canalizou $\mathrm{o}$ descontentamento provocado pela orientação conservadora dos primeiros governos, contrapondo-lhe um projecto reformador mais industrialista, proteccionista e anti-britânico, indo assim ao encontro dos interesses da exígua burguesia manufactureira e dos assalariados de Lisboa e Porto. Por outro lado, é conhecido o papel que os clubes, as Guardas Nacionais e os operários arma-

(u) De facto, entre Dezembro de 1833 e 1836, Silva Carvalho ocupou por várias vezes a pasta da Fazenda; entre 1832-36, Agostinho José Freire foi ministro da Guerra, Estrangeiro e do Reino. Cf. Oliveira Martins, Portugal Contemporâneo, vol. 3, Lisboa, Guimarães \& C. ${ }^{\text {a }}$ Editores, 1953, p. 326.

(u) José Liberato Freire de Carvalho, Memorias com o titulo de Annaes, para a historia do tempo que durou a usurpação de D. Miguel, t. IV, Lisboa, Imprensa Novessiana, 1843, p. 70.

(13) Idem, ibidem.

(M) Sobre o setembrismo, veja-se, entre outros, Victor de Sá, ob. cit., pp. 70 e ss. 


\section{A Maçonaria e a Restauração}

dos do Arsenal $\left({ }^{15}\right)$ tiveram na preparação e na eclosão da revolta, e não passou despercebida a presença de figuras ligadas à Maçonaria do Sul e à Maçonaria do Norte em lugares de relevo (16) nas comissões revolucionárias e nos governos setembristas. Mas se tudo isto é verdade, e embora nos faltem fontes directas para o demonstrarmos cabalmente, estamos em crer que a presença das maçonarias nos acontecimentos de Setembro necessita de alguns esclarecimentos e precisões, sob pena de se não relevar a natureza conflituosa da militância maçónica neste período.

$\mathrm{Na}$ verdade, julgamos que indicia os elos estreitos então existentes entre as maçonarias e a política o facto do poder revolucionário ter caído nas mãos dos mais altos dignatários dos Orientes anti-carvalhistas: Passos Manuel e o Conde de Lumiares. O primeiro, já o sabemos, era o grão-mestre da Maçonaria do Norte, enquanto o segundo terá sido um dos grãos-mestres interinos que governou a Maçonaria do Sul depois do afastamento de Saldanha $\left({ }^{17}\right)$. Quer isto dizer que, a par e em correlação com a actividade dos clubes do Camilo, da rua da Emenda e do Arsenal, o movimento setembrista contou nos bastidores com a mobilização dos dois Orientes mais radicais. Logo, não basta afirmar, em abstracto, a presença da maçonaria neste processo, já que, em face do que atrás ficou escrito, a ascensão de uma corrente tinha de passar pelo combate à que até aí dominava.

Com efeito, após a vitória, os setembristas terão procurado pôr em causa as posições que os elementos pertencentes ao Grande Oriente Lusitano ocupavam no aparelho de estado. E, para isso, não necessitaram de colocar a luta no campo estritamente maçónico, embora a contestação política se tenha repercutido, necessariamente, nesse domínio. E se o estado actual das investigações não nos permite ir muito longe, um documento emanado do seio do Grande Oriente Lusitano não deixa de reflectir este choque, ao acusar que «a revolução de Setembro de 1836,

(") No que respeita às ligações do Arsenal com o radicalismo político da época, leia-se Maria de Fátima Bonifácio, «Os arsenalistas na revolução de Setembro», Análise Social, n. ${ }^{\circ} 65$, vol. 17, 1981, pp. 26-61.

(ie) Victor de Sá, ob. cit., p. 84.

(1T) O desvio direitista de Saldanha levou-o a afastar-se das actividades maçónicas, tendo sido processado em 1837. A Maçonaria do Sul terá sido governada interinamente por José Liberato Freire de Carvalho, Conde de Lumiares e Luís Ribeiro Saraiva. Cf. Miguel António Dias, Annaes e Codigo de Pedreiros Livres, p. 59. Sobre a militância maçónica do general, consulte-se a carta de Saldanha a Reis e Vasconcelos em O Conimbricense, n. ${ }^{\circ}$ 2627, 27-IX-1872, p. 3. 
apesar de não ter encontrado oposição imediata e armada, criou logo nos vencedores um desejo de inexorável vingança.... Não houve, é verdade, perseguição aparente e directa por motivos maçónicos: mas foram demitidos de seus empregos (debaixo de pretextos diversos) alguns Funcionários Públicos porque pertenciam a LL/. do Or/, legítimo, e fizeram-se ameaças mui positivas a todos os demais membros daquelas LL.I, chegando a perversidade de alguns Escritores do partido então dominante (que se diziam Mações) ao mais subido ponto da escala: não só divulgaram nomes, locais e horas de reunião, mas até pediram ao Povo que fosse fazer justiça por suas mãos» ( $\left.{ }^{18}\right)$.

Que se sugere aqui? Que as perseguições políticas atravessavam a fraternidade maçónica e esta luta não foi estranha à criação do clima que culminou no linchamento do grande-administrador do Grande Oriente Lusitano (Agostinho José Freire) aquando da belemzada (19). E para se ter uma ideia da inimizade que alguns sectores populares tinham a este ministro de governos «devoristas», repressor do clube dos Camilos — mandou-o fechar a 7 de Maio de 1836 —, relembre-se que o seu assassinato se deu de um modo violentíssimo. Depois de ter sido morto no interior do transporte que o conduzia ao Paço, os revoltosos ter-lhe-ão tirado «decorações, dinheiro e vestidos», levando-o nu numa «pobre maca à vala comum de um cemitério entre imprecações, e blasfémias de alguma plebe furiosa» $\left({ }^{20}\right)$. Esta agitação obrigou alguns dos vencidos ao exílio - como aconteceu com José da Silva Carvalho $\left.{ }^{21}\right)$ - ou à retracção das suas actividades. Isto é, e como dizia um documento maçónico da época, a revolução terá mudado a «face política do país» $\left({ }^{22}\right)$ e, em consequência das ligações existentes entre a maçonaria carvalhista e a política dos primeiros gover-

(18) Manifesto do Gr.-- Or.-. Lus.-, p. 4. Este documento tem a data de 24 de Schebut de 5836 (13 de Fevereiro de 1837).

(19) «O Gr.l Adm.*., no momento que obedecia à ordem que recebera para apresentar-se no Paço, foi bárbaramente assassinado; e o Gr.l M. $\mid$ teve de expatriar-se, para não experimentar sorte igual» (Manifesto do Gr.' '. Or.'. Lus.'., p. 5). Registos destes acontecimentos encontram-se igualmente em Marques Gomes, ob. cit., pp. 253-55 e José de Arriaga, ob. cit., pp. 187 e ss.

C20) Resumo Historico da Vida e Tragico Fim de Agostinho José Freire..., Lisboa, Typ. Patriotica de C. J. da Silva, 1837, p. 21.

$\left.C^{21}\right) E$ isto apesar das promessas de protecção que Passos Manuel the deu. Cf. António Viana, Documentos para a Historia Contemporanea. José da Silva Carvalho e o seu tempo..., vol. 2, Lisboa, Imprensa Nacional, 1894, pp. 297-98.

(22) José Joaquim d'Almeida Moura Coutinho, Manifesto do Ir. '. Lycurgo, Gr.। Imp.:. Gr.'. da Ordem dos Franc-Maçons em Portugal, Ferrol, Imprenta de F. S. y A., 1849, p. 6. 


\section{A Maçonaria e a Restauração}

nos liberais, a subida ao poder do setembrismo implicou, logicamente, o imediato declínio do Oriente moderado.

\section{A queda de José da Silva Carvalho}

Com o exílio do grão-mestre, o Grande Oriente Lusitano, acéfalo e receoso de perseguições políticas, entrou numa fase de inacção nos meses seguintes a Setembro de 1836* A maioria das oficinas caiu em dormência ou abateu colunas, ficando a sua actividade reduzida ao protegido, porque afastado, núcleo açoreano (as lojas Amor da Liberdade, sediada na Horta e Valor e Constância, ao Oriente de Angra do Heroísmo) e à loja União, situada em Lisboa $\left({ }^{23}\right)$. Quer isto significar que o vendaval setembrista quase varreu por completo a maçonaria cartista. E só quando «os delírios da revolução começaram de perder a sua força» $\left({ }^{24}\right)$ e «os homens, que haviam fugido à fúria dos anarquistas, foram pouco a pouco voltando à cena pública» $\left({ }^{25}\right)$, o Oriente retomou novo folego, em correlação directa com a recuperação que os vencidos foram paulatinamente fazendo do processo revolucionário. A iniciativa da reorganização terá partido das lojas 24 de Julho e Concórdia $X^{2 *}$ ), entretanto despertas, as quais, em face da decadência da maçonaria tida por regular, lançaram uma campanha para a sua reforma, o que passava, previamente, pela eleição de novos altos dignatários.

Como se compreende, este assomo foi directamente condicionado pelo refluxo do radicalismo e pelas tendências consensualizadoras que os sectores mais moderados de ambas as facções liberais em luta começaram a defender. E se é certo que a Constituição de 1838 consubstanciou politicamente este desiderato, não será transposição mecânica integrar na mesma estratégia as intenções formuladas, na época, por alguns mações dos três Orientes ao defenderem a reconstituição da: unidade maçónica. De facto, existem sinais de que o relançamento autónomo do Grande Oriente Lusitano foi acolhido com reticências por certos obreiros que pensavam estarem reunidas as condições propícias à junção das maçonarias até aí em luta. Segundo nos informa Miguel António Dias, muitos cavaleiros Rosa Cruzes, pertencentes aos três Orientes, terão lançado, em 1837, um veemente apelo à concórdia maçónica: «Os CC.।

$\mathrm{C}^{23}$ ) Idem, ibidem, p. 7.

D Manifesto do Gr.| Or. $\backslash$ Lusitano, p. 6.

$\mathrm{C}^{25}$ ) Idem, ibidem.

(M) José Joaquim d'Almeida Moura Coutinho, ob. cit., pp. 8-9. 


\section{Revoltas e Revoluções}

RR.I CC.I, reunidos em Círculo, dirigem-se, com esta respeitosa Representação, a cada um dos 3 GG.। $00 .{ }^{*}$., que se acham reconhecidos pelas 3 facções actuais e mais ou menos amplas da Maç.l Lus. $\backslash$, e pedem-lhes por decoro da mais Aug.l das Ord. $\$ que professamos, pela salvação da Liberdade, e da Pátria, hajam por bem entabular entre si negociações de tal forma razoáveis, que prontamente se consiga a Reunião, e Concórdia de toda a Maç.*. Lus.।, reconhecendo-se nela uma só Família, uma só Constituição, e um só G.\O.*.»( (27). Projecto prematuro, já que, como as lutas da década seguinte o irão demonstrar, os interesses entre as facções liberais continuaram inconciliáveis, o que impedia a formação de um bloco político duradouro e, consequentemente, a unificação das maçonarias. Deste modo, se os apelos em prol da fusão não foram ouvidos, a reorganização do Grande Oriente Lusitano ganhou grande ênfase, enquanto se iam destruindo as «bolsas» em que o radicalismo se apoiava.

Se para os elementos activos da maçonaria cartista a prossecução dos esforços reformadores seria impossível sem as eleições para os altos cargos maçónicos, o exílio de Silva Carvalho e o facto das leis da Ordem em vigor não permitirem a reeleição consecutiva do grão-mestre levaram algumas lojas, lideradas pela oficina 24 de Fevereiro (28), a convocar um congresso $(22-X-1839)$ para decidir acerca da governação do Oriente. Para grão-mestre foi escolhido o velho liberal Manuel Gonçalves de Miranda (Senaclnerib), tendo José da Silva Carvalho sido eleito para o lugar de grande-administrador (o segundo mais importante na hierarquia) $\left({ }^{29}\right)$.

Para muitos, a invocação da impossibilidade legal de reeleição do antigo grão-mestre só serviu para encobrir os desígnios dos que há muito preparavam a queda do «irmão» Hidaspe. $\mathrm{O}$ próprio visado assim o entendeu, pois recusou-se a aceitar o cargo subalterno, vindo a cindir para formar uma agremiação maçónica autónoma. Mas para um contestário da eleição de Gonçalves Miranda e defensor de Silva Carvalho, tais cisões deviam ser aproveitadas para se alcançar um outro objectivo: unir as lojas fiéis ao antigo grão-mestre às maçonarias setembristas através de uma estrutura paritária de modo a conseguir-se bloquear as intenções dos que tinham tomado o poder

${ }^{(27)}$ In Miguel António Dias, Architectura Mystica do Rito Francez ou Moderno, p. 260.

(28) José Joaquim d'Almeida Moura Coutinho, ob. cit., p. 9.

$\left.{ }^{29}\right)$ Miguel António Dias, ob. cit., p. 262, e Annaes e Codigo dos Pedreiros Livres, p. 59; José Joaquim d'Almeida Moura Coutinho, ob. cit., pp. 86 e ss.; Borges Graínha, ob. cit., pp. 108-110. 
no Grande Oriente Lusitano $\left.{ }^{(30}\right)$. No entanto, nada disto teve qualquer eco e da crise resultou, somente, o aparecimento de uma nova organização maçónica $\left({ }^{31}\right)$, continuando em aberto as desinteligências. anteriores.

\section{O grão-mestrado de Manuel Gonçalves Miranda}

Com efeito, tal como as Maçonarias do Norte e do Sul, também o Grande Oriente Lusitano prosseguiu o seu caminho, numa conjuntura cada vez mais favorável. Manuel Gonçalves Miranda subiu ao grão-mestrado e nos finais de 1839 conferia posse às demais altas dignidades $\left({ }^{32}\right)$, do seio das quais se começou a destacar o então ainda grande-vigilante interino, José Joaquim d'Almeida Moura Coutinho (Licurgo). E, ao que parece, a governação da nova liderança terá sido eficiente, pois não só muniu o Oriente de um novo catecismo e de uma nova Constituição ${ }^{33}$ ) - obras escritas por Coutinho - como conseguiu animar um activismo que, em 1839, estaria alicerçado em mais de dezena e meia de oficinas $\left({ }^{34}\right)$.

$\left.C^{\circ}\right)$ Veja-se a Resposta ao honroso e lisonjeiro manifesto de alguns que se intitulam Gr.I Or.I Lusitano. Este escrito tem a data de 12 de Março de 1840 e é assinado por O'Connel (D. Francisco de Judicibus?).

(31) Sobre este Oriente - o Supremo Conselho do Grau 33 do Rito Escocês Antigo e Aceite para Portugal - vejam-se José Joaquim d'Almeida Moura Coutinho, oh. cit., pp. 59-60; N. dos Reis e R. Felner, Almanak do rito escocez antigo e aceite para Portugal, para o anno de 5845, Lisboa, Tÿpographia de O. R. Ferrer, 1845, O Nível, n. ${ }^{\circ} 14$, I anno, 1884, p. 57.

(32) A.U.C., Legado de Fausto de Quadros [Actas da instalação de altas dignidades do Grande Oriente Lusitano], fis. 1 e ss.

Cf. Constituição da Maçonaria Portugueza decretada $e$ sanccionada aos 30 do m.| Tisch'ri do an.'. da V.I L.I 5840 pela Gr.। Dieta Geral Constituida e Constituinte da Maçon.'. Luzitana Gr.\ O.-. L.I, [20 de Setembro de 1840].

$C^{34}$ ) Sem a pretensão de sermos exaustivos - só a consulta de arquivos poderá confirmar o que nos informam as fontes impressas da época - o quadro orgânico do Grande Oriente Lusitano contaria, em 1839, com as seguintes lojas: Lisboa (24 de Julho, União, Concórdia, 28 de Julho, Perseverança, Firmeza, Prudência, Firmeza e Valor); em Coimbra (D. Pedro); Porto (Legalidade); Pombal (Perseverança); Ponta Delgada (União Açoreancú); Angra (União $e$ Valor ${ }^{1}$ ); Horta (Amor e Liberdade); Funchal (Constância). Para esboçar esta lista servimo-nos das seguintes fontes: Manifesto do Gr.-. Or.'. Lus.;., s. e., s. d., pp. 10-11; José Joaquim d'Almeida Moura Coutinho, ob. cit., p. 16. Esta última obra não regista as lojas Prudência e Legalidade; por sua vez, das mencionadas por Coutinho, o Manifesto só não se refere à loja Constância. 


\section{Revoltas e Revoluções}

Isto revela que a maçonaria cartista recuperou alguma da sua influência perdida em Setembro de 1836. Com a liquidação do apoio que os setembristas tinham no seio das Guardas Nacionais (1838) (35) e com as manobras palacianas, tuteladas por Londres, procurando um equilíbrio à volta da nova Constituição, o activismo maçónico de pendor moderado podia progredir. $\mathrm{O}$ governo de Novembro de 1839 - onde figuravam setembristas arrependidos (António da Costa Cabral) e cartistas - soava como o dobre de finados do radicalismo ( ${ }^{3 C}$ ) e exprimia a nova ordem. Daí não admirar que, após cinco anos da revolução de Setembro, o grão-mestre do Grande Oriente Lusitano fosse de novo chamado ao governo (Janeiro e Março de 1841). Que melhor exemplo se pode evocar para exprimir o sentido da evolução política nos finais da década de trinta? E se não existem dados seguros para se esclarecer o peso do Oriente no fomento deste percurso, o mesmo não acontece no que concerne ao seu desfecho: a restauração da Carta Constitucional banida em 1836. De facto, e como se irá demonstrar, o Grande Oriente Lusitano desempenhou um papel importante no processo que levou ao golpe de Costa Cabral em 1842.

Diga-se que tal comprometimento surge como uma consequência natural das suas características orgânicas e ideológicas. É que, num país com uma débil organização proto-partidária e em que o controle da luta política se confinava ao círculo restrito das novas élites, a sua força tinha de se fazer sentir, tanto mais que, como nos restantes Orientes, também a sua prática maçónica continuava fiel à politização dos anos anteriores. E se alguns obreiros começavam a defender que os cultores da Arte Real se deviam demarcar da instrumentalização política, o certo é que a grande maioria estava nas lojas para as transformar em «Clubes políticos» $\left({ }^{37}\right)$, capazes de «lhes servir de meio de influir na política do país» ( $\left.{ }^{38}\right)$ e de combater «as criminosas tentativas doutras Sociedades igualmente secretas, mas de natureza oposta e positivamente decididos a subverter o Estado e a entregar-se ao punhal dos anarquistas» $\left({ }^{39}\right)$.

$C^{35}$ ) Sobre a acção de Costa Cabral contra as Guardas Nacionais, veja-se José de Arriaga, ob. cit., t. III, pp. 68 e ss.

(36) As linhas essenciais do processo político que levou ao gradual esvaziamento da revolução setembrista e à crescente hegemonia das forças mais conservadoras encontram-se descritas, ainda que de um modo unilateral e apaixonado, em José de Arriaga, ob. cit., t. Ill, passim; sobre o mesmo assunto, consulte-se com proveito J. Barbosa Colen, História de Portugal e Illustrada de Manuel Pinheiro Chagas..., vol. 10, Lisboa, Empreza da História de Portugal, 1905.

(37) José Joaquim d'Almeida Moura Coutinho, ob. cit., p. 26.

(") Idem, ibidem, p. 20.

(39) Manifesto do Gr.-. Or.-. Lus.-., p. 7. 
Assim sendo, compreende-se que os aspirantes a posições de liderança, e os que sonhavam com a restauração ¿artista, cobiçassem os meios humanos e financeiros oferecidos por este Oriente. Isto é, e como sublinhou, na época, um admirador de Costa Cabral, era de boa táctica e de «sábia precaução, aproveitar como alavancas governativas essas associações, que se tornam tão poderosas, e temíveis, se se abandonam nas mãos dos inimigos» $\left({ }^{40}\right)$. Como conseguiu António da Costa Cabral concretizar o seu domínio sobre este meio de combate político?

\section{A ascensão de Costa Cabral ao grão-mestrado do G.O.L.}

A morte de Manuel Gonçalves Miranda (5 de Abril de 1841) $\left({ }^{41}\right)$ veio abrir, de novo, o problema do governo do Grande Oriente Lusitano. De imediato, começou a defender-se $\left({ }^{42}\right)$ o nome de Rodrigo da Fonseca Magalhães (Aristides), velho mação que, por essa altura, era uma das figuras proeminentes do governo do país ( ${ }^{43}$ ), situando-se na ala dos que, embora não concordassem com a ordem constitucional instaurada em 1838, aceitavam o statuto quo e não pareciam dispostos a recorrer a meios violentos para repor a Carta Constitucional. Porém, para surpresa de muitos, surge a candidatar-se ao cargo o seu novo rival na chefia do liberalismo ordeiro, o ministro da Justiça e dos Negócios Eclesiásticos, António da Costa Cabral. Na verdade, desde há muito que se vinham notando os esforços deste último para impor a sua imagem no seio do governo formado a 26 de Novembro de 1839 para pacificar a situação política, confrontando-a com as personalidades mais chegadas ao Paço, onde Fonseca Magalhães gozava de indiscutível prestígio. Mas, o que aqui nos interessa, é salientar como é que esta compita se traduziu em termos maçónicos. Ora, para isso, impõe-se responder a esta questão prévia: como é que um ex-radical apareceu habilitado a concorrer ao mais alto cargo de um Oriente moderado?

É conhecido que António da Costa Cabral foi um dos

(40) Príncipe Lichnowsky, ob. cit. $f$ p. 66.

(41) José Joaquim d'Almeida Moura Coutinho, ob. cit., p. 40,

(42) José de Arriaga, ob. cit., t. III, pp. 538-39.

(43) Velho conspirador de 1817 , ter-se-á salvo da forca por ter conseguido ludibriar a polícia. Deve ter-se iniciado em 1807, quando, em Coimbra, cursava Teologia. Cf. Joaquim Martins de Carvalho, Apontamentos para a Historia Contemporanea, Coimbra, Imprensa da Universidade, 1868, p. 47. 
principais activistas (44) do clube do Arsenal no período da revolução de Setembro, lugar onde terá exercitado as suas qualidades oratórias. E como esta agremiação, que foi um dos baluartes do movimento revolucionário, estava articulada com o activismo das maçonarias mais radicais, não surpreende que o encontremos a militar na Maçonaria do Sul. Com efeito, embora não possamos precisar a data da sua filiação, sabemos que se iniciou na oficina Emigração Regeneradora com o nome simbólico de Fénelon. Esta loja foi fundada em Paris, em 1830, por indivíduos «só Académicos e Doutores» (45). Por esta altura funcionou «sempre independente dos Orientes acima ditos» $\left({ }^{46}\right)$. Em 1834, com a vitória liberal, transferiu-se para Lisboa e, segundo um dos seus veneráveis, continuou autónoma durante um ano, momento em que «se filiou no Or.*, de Saldanha. Aos seus quadros, que chegaram a ter 62 membros, pertenceu António Bernardo da Costa Cabral» $\left({ }^{47}\right)$.

Deste modo, não se pode estranhar que, nesta fase, o futuro ministro militasse na Maçonaria do Sul, do mesmo modo que se compreende que, em face da sua evolução logo a seguir à revolução de Setembro, em que se notabilizou como perseguidor das Guardas Nacionais (1838), bastião militar setembrista, a sua loja o tenha julgado e expulso (48). E num momento em que as personalidades políticas de todas as facções recorriam a núcleos proto-partidários de suporte, não admira também que um ambicioso como Cabral se tenha voltado para o Grande Oriente Lusitano $\left({ }^{49}\right)$. $\mathrm{Na}$ verdade, ter-se-á inscrito na loja União $\left(^{50}\right)$, presumivelmente no início da década de quarenta, tendo sido acompanhado pelos seus dois irmãos: José da Costa Cabral (Catão 2. ${ }^{\circ}$ ) e João Rebelo (Viriato).

$\left({ }^{44}\right) \quad$ «Diz-se, que membro dum clube.... PEDIRA NUM ACESSO

DE RAIVA A CABEÇA DA RAINHA!!!" (Costa Cabral Em Relevo ou Memoria Biographica D'Este Ministro para Servir d'Auxiliar A História do Dia, 2.a ed., Coimbra, Typographia da Opposição Nacional, 1844, p. 12); vejam-se igualmente pp. 19-20.

i ${ }^{45}$ ) Miguel António Dias, Architectura Mystica do Rito Francez ou Moderno, p. 259, nota 1.

$i * 9)$ Idem, ibidem.

(4T) Idem, ibidem, p. 260 , nota 1.

$\left.i^{49}\right)$ "O Ir.*. Antonio Bernardo da Costa Cabral, depois de ter sido processado por L.I Emigração Regeneradora em 1838, foi filiar-se na L.I União do Rit.-. Esc.*., para poder ser eleito Gr.। Mest.*.» (Miguel António Dias, Annaes e Codigo dos Pedreiros Livres, p. 60).

${ }^{49}$ ) Subalternizado no governo da «nova ordem»- onde a figura de proa era Rodrigo da Fonseca Magalhães — ter-se-á voltado para o Grande Oriente Lusitano a fim de, no dizer de um contemporâneo anónimo, se servir «do maqumismo secreto das sociedades maçónicas» (Costa Cabral em Relevo...., p. 34).

(M) José Joaquim d'Almeida Moura Coutinho, ob. cit., p. 44. 


\section{A Maçonaria e a Restauração}

Após a morte do grão-mestre, a sua loja lançou-se, de imediato, na campanha a favor do nóvel filiado, embora, ao que parece, este se tenha mostrado tácticamente surpreendido quando aquele lugar the foi oferecido contra a candidatura de Rodrigo da Fonseca Magalhães ( ${ }^{51}$ ). E não deixa de ser revelador o sentido dos argumentos mobilizados pelos seus prosélitos para justificar a candidatura. Cabral, vindo do campo dos adversários políticos, seria a personalidade indicada para continuar a luta contra o setembrismo: «Encarecia-se a sua energia, e a disposição em que estava de sustentar a causa da ordem pública; .... fazia-se crer que aos seus esforços fora devido o aniquilamento da hidra revolucionária.... de 1838; e pretendia-se que ele, com este serviço, tinha purgado os seus erros e desvarios anteriores; afeava-se finalmente o perigo da situação maçónica, para se crer na necessidade de um homem, na sua posição, que pudesse anular os manejos dos MMaç.। dissidentes» ( $\left.{ }^{52}\right)$. Esta propaganda teve como impulsionador José da Costa Cabral, também membro da loja União, e foi tão eficaz que, no dizer de Moura Coutinho, «souberam dispor os ânimos e alcançar uma vitória que surpreendeu a Maç.। inteira» (53).

De facto, sucedendo ao interinato de Bartolemeu dos Mártires Dias de Sousa, Costa Cabral venceu as eleições, enquanto Rodrigo da Fonseca Magalhães foi o mais votado para o cargo de grande-administrador. E a 6 do mês de Jiar do ano de 5841 ( 26 de Abril de 1841) era instalado com toda a solenidade da praxe no novo cargo $\left.{ }^{54}\right)$. Rodrigo não aceitou o seu $\left({ }^{55}\right)$, abandonando o Oriente para se aproximar da maçonaria de José da Silva Carvalho. Por aqui se vê como o choque político entre aquelas duas individualidades se repercutiu no interior da maçonaria.

Com a sua eleição, o novo grão-mestre passou a dispor de

(51) Cf. Costa Cabral em Relevo...., p. 35.

(") José Joaquim d'Almeida Moura Coutinho, ob. cit., p. 45. Confirmando esta reabilitação, um historiador oitocentista escreveu: «A guarda nacional estava dissolvida, o exército em grande parte estava do seu lado. Os homens da revolução estavam sem força para a resistência, os ordeiros, esses, perdoavam-lhe todas as suas antigas exagerações demagógicas, todos os perjúrios, contando que ele desse cabo da hidra» (António Maria Baptista, Uma Década da Historia Contemporanea 1838-1848, Lisboa, Typ. de Alfredo da Costa Braga, 1888, p. 61).

i83) José Joaquim d'Almeida Moura Coutinho, ob. cit., pp. 45-46; M. Borges Grainha, ob. cit., p. 119-20.

$\left.{ }^{54}\right)$ Uma cópia da acta desta cerimónia, bem como a da instalação de outras altas dignidades do G.O.L., encontra-se no A.U.C., Legado de Fausto de Quadros. Instalação do Ir. Fenelon, Gr. Mr. da Maç.।. on.| Lusit.fis. 31-36.

(") Cf. J. Barbosa Colen, ob. cit., vol. 10, pp. 483-87. 


\section{Revoltas e Revoluções}

um meio não despiciendo para o prosseguimento da sua carreira política. É que, como vimos, o Grande Oriente Lusitano definia-se como uma maçonaria militantemente anti-radical e anti-setembrista, para além de contar com uma organização significativa para a conquista e para a consolidação do poder político. Por outro lado, o associativismo maçónico permitia a angariação de recursos financeiros passíveis de serem desviados das suas finalidades filantrópicas. Daí que, agora, importe demonstrar como é que a sua evolução acabou por possibilitar a instrumentalização cabralista, culminando na restauração da Carta Constitucional. Ora, sabe-se que nos inícios da década de quarenta, a situação política continuou tensa, tanto mais que a crise espanhola e as movimentações de Espartero a condicionavam directamente. E ainda que imediatamente esconjurado, o perigo radical continuava a ser uma realidade, enquanto o bloco conservador se dividia em duas facções essênciais: a «ordeira» e a que sonhava com o regresso à ordem constitucional anterior a $1836{ }^{(56)}$. A primeira, liderada por Rodrigo da Fonseca Magalhães, António José de Ávila e outros ministros, tinha o apoio da Inglaterra e do Paço e pautava-se pela seguinte lógica política: preferia gerir moderadamente os negócios públicos de acordo com a Constituição de 1838, do que embarcar numa aventura golpista, cujo desfecho poderia levar à reconstituição de uma frente setembrista-miguelista e a um de dois epílogos: ou um governo radical, pró-francês e iberista (já que esta vitória implicaria a queda de D. Maria e instituiria uma monarquia electiva liderada pela princesa Amélia, filha do segundo casamento de D. Pedro, ou pela infanta Isabel Maria, irmã do mesmo rei), ou à hegemonia legitimista com o regresso de D. Miguel. Naturalmente, nenhuma destas alternativas agradava a Londres e daí a resistência do seu embaixador a qualquer acção ilegal. A segunda facção, ainda que publicamente pouco assumida, era perfilhada pelo grupo que apoiava António da Costa Cabral. Como se reflectiu tudo isto dentro da maçonaria cartista?

\section{O golpe de estado de Costa Cabral e o Grande Oriente Lusitano}

Há indícios que apontam para a existência, no seio do Grande Oriente Lusitano, de alguns receios no concernente ao

C56) Para uma análise destas tendências e da influência inglesa na conjuntura, veja-se Maria Fátima Bonifácio, «1834-42: a Inglaterra perante a evolução portuguesa (hipótese para a revisão de versões correntes)», Análise Social, vol. 20, n. ${ }^{\circ} 83,1984$, pp. 467-88. 


\section{A Maçonaria e a Restauração}

novo grão-mestrado. Conhecedores do temperamento de Costa Cabral, os obreiros mais ritualistas e, por isso, mais renitentes ao comprometimento político da Ordem, temeram as consequências decorrentes da sua previsível partidarização. Contudo, os primeiros movimentos do «irmão» Fénelon foram cautelosos: procurou evitar o debate de questões polémicas e revelou uma assiduidade aos trabalhos que surpreendeu mesmo os mais receosos. As dúvidas acerca das suas intenções só terão reaparecido quando começou a suscitar o debate da situação política $\left({ }^{57}\right)$ e, sobretudo, quando se deu a entrada de pedidos de regularização de lojas erguidas exclusivamente por militares $\left({ }^{58}\right)$. Com efeito, se a legalização das duas primeiras oficinas com estas características não levantou grandes objecções, o mesmo não aconteceu com a terceira, cujo pedido, formulado a 7 de Setembro de 1841, originou «diferentes reflexões» $\left({ }^{59}\right)$, conquanto a regularização acabasse por ser aprovada. Quando a 2 de Novembro do mesmo ano, surgiu uma nova pretensão vinda do Funchal e também de origem militar, a Grande Loja votou contra, escudando-se na oposição de uma oficina madeirense e do respectivo venerável, o comandante militar da Ilha $\left({ }^{60}\right)$. E se razões regionais e pessoais podem ser aduzidas para se justificar a recusa, o motivo que ditou a oposição de uma maioria significativa daquela instância maçónica chamou a terreiro os perigos de «militarização» do Oriente, tendência que encobriria o plano de «formar uma coligação para estabelecer a exclusiva influência, e o predomínio da classe militar sobre todas as outras do Estado» (61).

$\mathrm{Na}$ fase actual da investigação, não se pode saber, com segurança, em que medida é que esta penetração militar no Grande Oriente Lusitano foi comandada ou não pelos Cabrais. No entanto, para além dos aspectos subjectivos do problema, três realidades ressaltam, de imediato, da sua análise. A primeira diz respeito ao facto de esse surto ter aparecido depois da eleição de Costa Cabral para grão-mestre, o que per-

(5T) A 2 de Julho de 1841, Costa Cabral contactou a Grande Loja e a Grande Dieta «para lhes expor o estado do país, as ocultas desinteligências ministeriais, as intrigas palacianas, e até os actos e confidências de Augustas Personagens, pedindo conselho para dirigir-se nas diferentes hipóteses e nas diversas questões que propôs») (José Joaquim d'Almeida Moura Coutinho, ob. cit., p. 61).

(58) Idem, ibidem, pp. 64 e ss.

(59) Idem, ibidem, p. 65.

(60) Idem, ibidem, p. 66.

(®) Idem, ibidem, p. 67. Mais concretamente, o pedido de regularização da quarta loja apareceu já sob a égide de um Capítulo formado por elementos das lojas militares. 


\section{Revoltas e Revoluções}

mite concluir que a sua ascensão criou, pelo menos, um clima propício ao crescimento da influência de certas camadas do exército na maçonaria cartista (62). A segunda é ainda mais objectiva: estas ligações foram desde logo interpretadas, por testemunhas bem colocadas, como uma manobra cabralista para preparar o golpe. Na verdade, pelo menos para o embaixador inglês, outra não foi a função de tais oficinas: o "groundwork has been prepared previous to his becoming last year the Grand Master of the Chartist Masons Clubs » (63), em aliança com o «power and aid of the military» $\left({ }^{64}\right)$, consolidada através de «military clubs.... with the cooperation and sanction of the Duke of Terceira» $\left({ }^{65}\right)$. E os factos provam que o Grande Oriente Lusitano e as lojas militares desempenharam um papel decisivo na eclosão e na consolidação do golpe restauracionista de 27 de Janeiro de 1842.

A ser assim, continua controversa a questão de se saber se Costa Cabral planeou pormenorizadamente o movimento que derrubou a Constituição de 1838 , ou se, pelo contrário, se limitou a aproveitar um momento propício. Não temos, no entanto, quaisquer dúvidas de que, previamente, fosse para se rebelar ou tão-só para aumentar o seu poder, se foi munindo dos meios então adequados e quase exclusivos de pressão e de conquista do aparelho de estado: a maçonaria e o exército. O seu percurso maçónico já ficou delineado. Por outro lado, deve-se ter presente a sua acção preambular como administrador de Lisboa voltada para a destruição dos núcleos armados que reforçavam a esquerda (Guardas Nacionais), e o aparecimento das lojas militares tem de ser visto como uma tentativa para articular a maçonaria com algumas unidades do exército de linha estrategicamente bem colocadas. Com efeito, basta sublinhar que, no golpe, tais lojas operaram sobre o Castelo, para se compreender, pelo menos na capital, a importância daquela ligação.

Nesta perspectiva, torna-se difícil aceitar a tese, geralmente sustentada pelos prosélitos de Cabral, segundo a qual o golpe foi o produto de uma mera conjuntura. É que não se

(65) Também para Teixeira de Macedo, embora escrevesse em 1880, não existiam dúvidas: Costa Cabral «tratou de segurar o exército filiando muitos oficiais e sargentos nas lojas maçónicas» (António Teixeira de Carvalho, Traços de História Contemporânea 1846-1877, Lisboa, Edições Rolim, 1984, p. 50).

$C^{63}$ ) Carta n. ${ }^{\circ} 45$, de 27 de Fevereiro de 1842 (Foreign Office, 63-544), in M. Fátima Bonifácio, «1834-42. a Inglaterra....», cit., p. 485, nt. 58).

$O$ Carta n. ${ }^{\circ} 18$, de 29 de Janeiro de 1842, in idem, ibidem.

$C^{5}$ ) Carta $n .^{\circ}$ 19, de 30 de Janeiro de 1842, in idem, ibidem. 


\section{A Maçonaria e a Restauração}

pode desmentir que o ministro da Justiça passou a dirigir uma maçonaria que colocou ao seu serviço, embora, no caso do Grande Oriente Lusitano, a existência de algumas resistências a aventuras políticas o obrigasse a recorrer à mesma táctica que utilizou no que concerne aos cartistas moderados (66) e às hesitações do Paço fomentadas pela pressão inglesa: a criação de um facto consumado que, perante os perigos esquerdistas advindos da possível derrota da conspiração, obrigasse todos os sectores conservadores a defendê-la e a torná-la vitoriosa. Daí a ambiguidade com que, em Janeiro de 1842, se apresentou no Porto $\left({ }^{\circ}\right)$ : pôs-se à frente dos contestónos com esta dupla intenção: mostrar ao Paço e aos moderados que o movimento surgia como uma exigência popular e, aos seus adeptos, que o golpe cumpria os desejos da Rainha. E a todos, porém, levantava o mesmo fantasma: caso a sua acção não fosse secundada, isso provocaria a guerra civil e despertaria a hidra revolucionária.

Ora, se esta interpretação pode parecer abusiva, o que aconteceu no seio do Grande Oriente Lusitano nas vésperas do golpe não nos permite, por ora, chegar a outra conclusão. Vários testemunhos são unânimes no registo do contributo das lojas do Porto (União Portucalense e Legalidade?) na agitação da opinião pública em prol da restauração da Carta. José Joaquim d'Almeida Moura Coutinho assinala o prévio trabalho que José da Costa Cabral aí fez, nos início de Janeiro ( ${ }^{68}$ ), e o atento Lavradio já a 12 consignava no seu diário: «O Ministro Costa Cabral pediu licença para ir ao Porto, com o motivo aparente de ir ver a sua família, ou parte dela, que ali se acha; dizem, porém, que o verdadeiro motivo desta viagem é promover, principalmente por meio da Maçonaria, uma reacção a favor da Carta de $1826 »\left({ }^{69}\right)$. Mas se foi isto que aconteceu no Porto, cidade

(ee) A perspectiva do liberalismo moderado contra o golpismo encontra-se exposta na «memória» que o então ministro José Jorge Loureiro escreveu. Está inserta em J. Barbosa Colen, ob. cit., vol. 10, pp. 513 e ss. vo...., pp. 28 e ss.

$\left({ }^{67}\right)$ Sobre o golpe de estado, veja-se Costa Cabral em Rele-

(68) Com efeito, o próprio António da Costa Cabral terá confessado, em sessão maçónica realizada a 10 de Março de 1842, que «o autor do projecto da revolução para a restauração da Carta, e o director de todos os trabalhos para ela, tinha sido o mesmo seu Irmão, ainda que ele tomara o primeiro lugar ostensivo, por assim convir ao movimento, em consequência de sua especial posição» (José Joaquim d'Almeida Moura Coutinho, ob. cit., p. 82).

(69) Memórias do Conde de Lavradio D. Francisco de Almeida Portugal, vol. 3, Coimbra, Imprensa da Universidade, 1934, p. 162. Para um prosélito de Cabral, a sua ida ao Porto terá sido ditada pela 


\section{Revoltas e Revoluções}

em que não encontrou grandes resistências, o que terá ocorrido não só no Paço, mas no seio do Grande Oriente Lusitano? Sabe-se que, ao nível da Gorte e do governo, o golpe não teve um acolhimento imediatamente favorável e só a sua evolução no norte do país terá convencido os hesitantes. Mas, aqui, interessa-nos tão-só particularizar a sua incidência nas lojas da capital e indagar como é que conseguiu demover a facção ritualista pouco receptiva ao comprometimento conspirativo. Já o dissemos: tal como actuou em relação à Corte, assim o fez face ao Grande Oriente Lusitano. Em vez de colocar as oficinas lisboetas a par das suas intenções, foi já no Porto, a 26 de Janeiro, que Cabral as informou do golpe $\left({ }^{70}\right)$ e pediu encarecidamente «o auxílio da Maç.|», invocando a agitação da opinião pública e a irreversibilidade dos preparativos da acção golpista. E foi «nessa mesma noite, em assembleia geral das três Câmaras, na rua do Alecrim, no Templo das LL.*. militares» $\left({ }^{71}\right)$, que se terá decidido apoiar o movimento, lançando-se a maçonaria «em trabalhos feito em Lisboa, e na Província», trabalhos que, «ainda que dirigidos exclusivamente pela Maç.*., foram todos, de sua natureza, políticos» $\left({ }^{72}\right)$.

Ora, não deixa de ser sintomático que, nos motivos que convenceram os mais renitentes a actuar, encontremos, de novo, o temor da revolução. Com efeio, «a única razão que determinou a Assembleia Maçón.। do dia 26 de Janeiro a apoiar o movimento que devia ter lugar no dia seguinte, foi o conhecimento do estado da opinião do Porto» ( ${ }^{73}$ ) e o medo de que, sem um forte apoio a Sul do Mondego e, em particular, na capital, a conspiração soçobrasse às mãos da coligação setembrista-miguelista apoiada pela passividade dos cartistas anti-golpistas. Isso seria o primeiro passo para o regresso dos radicais ao poder, ou para a abertura de uma crise de desfecho imprevisível. Em consequência, e ao contrário dos primeiros

intenção de evitar o recurso à violência: «O que levou Costa Cabral ao Porto foi usar a sua influência, não para acalmar os gritos a favor da Carta que todos queriam, mas para evitar que ela fosse proclamada revolucionariamente, receando os tristes resultados da revolução» (Memórias do Marquez da Fronteira e d'Aloma D. José Trazimundo Mascarenhas Barreto, Parte V e VI, Coimbra, Imprensa da Universidade, 1929, p. 322.

(TQ) «No entretanto em uma quarta feira, que se contaram 26 de Janeiro... recebíamos nós os MMaç.l a comunicação de que, no dia 27 pela manhã, a Carta Constitucional havia de ser aclamada na cidade do Porto.... O Gr.*. M. 1 pedia encarecidamente o auxílio da Maçon.*.» (J. J. d'A. Moura Coutinho, ob. cit., p. 72).

(71) Idem, ibidem.

(") Idem, ibidem, p. 73.

i73) Idem, ibidem, p. 74. 
esforços do embaixador inglês ( ${ }^{74}$ ), a decisão dos mações das lojas lisboetas do Grande Oriente Lusitano apontou para a adesão às pretensões de Cabral, não tanto para servirem os seus desígnios pessoais, mas por concluírem que a vitória era a solução que, naquele contexto, melhor salvaguardaria os interesses de D. Maria. Isto é, entraram no golpe para se «evitar um maior mal, salvar a Rainha, e salvar o país» (75).

Seja como for, o certo é que as oficinas da capital e, em concreto, as lojas militares que se tinham instalado no ano anterior, deram um contributo crucial para o sucesso do movimento $\left({ }^{76}\right)$. Sabemos que, para a articulação dos esforços conspirativos, formaram uma Comissão Salvadora (77), mobilizaram os fundos maçónicos $\left({ }^{78}\right)$ e, sobretudo, intensificaram a agitação nos quartéis. Esta acção clandestina teve o seu momento supremo no juramento cartista solenizado na loja Prudência, em Fevereiro, nas vésperas da restauração da Carta na cidade de Lisboa. Como afirmou um dos membros desta oficina «foi no nosso seio, foi nestas próprias mãos que Bravos e Valentes Militares prestaram um juramento solene, que pouco mais de 24 horas depois se realizaram! Viva a Carta.... Bradaram esses heróis no alto do antigo Castelo!» $\left({ }^{79}\right)$.

Com efeito, «no dia 8 antes do amanhecer, o Brigadeiro Eusébio Cândido, Governador do Castelo, de acordo com o coronel do $2 .^{\circ}$ de infantaria, Pimentel, e do 12 da mesma arma, Rebordo, proclamaram a Carta. Duas companhias do 10 de Infantaria abandonaram o Coronel Loureiro e vieram reunir-se

$\left.C^{4}\right)$ Cf. Maria de Fátima Bonifácio, art. cit, pp. 470 e ss.

(TC) José Joaquim d'Almeida Moura Coutinho, ob. cit., pp. 73-74.

C6) Idem, ibidem, pp. 72-73.

(") Cf. idem, ibidem, p. 75; Manuel Lobo de Mesquita Gavião, Breves Considerações Historicas e Criticas sobre as Eleições da Província do Minho no anno de 1845 com os seus respectivos documentos, Porto, Typographia de Faria Guimarães, 1845, p. IV. Moura Coutinho e Mesquita Gavião fizeram parte da Comissão Salvadora.

$\left({ }^{78}\right)$ Os movimentos de dinheiro para o custeamento do golpe em Lisboa podem ser comprovados pela correspondência da loja Razão Triunfante. A.N.T.T., Arquivo da Família Costa Cabral, c 17, est. 198-204, macete 75.

${ }^{(79)}$ Allocução pronunciada pelo I.। Ven.-. da R.| L.| Prudencia no dia da transladação do seu novo templo decimo sétimo anniversario do juramento da Carta Constitucional A.I da V.I L.I 5843 dedicado ao S.I G.। M.I da Maçonaria Luzitana, Impresso para se distribuir pelas RR.: LL.I do Circulo do G.। O.*. Luzitano, pelo $\mathbf{L} \backslash$ Mestre, Membro da R.। L *. Firmeza, p. 13. Relembre-se que só a 8 de Fevereiro, uma salva real feita pelos canhões situados no Castelo anunciou a Lisboa a restauração da Cárta. Cf. Oliveira Martins, ob. cit., vol. 3, pp. 20-21. 


\section{Revoltas e Revoluções}

aos seus camaradas no Castelo» $\left({ }^{80}\right)$. Sem pretendermos sustentar que todos eram mações, parece-nos, no entanto, demonstrada a presença da maçonaria no desenvolvimento do processo e, em particular, dos seus elementos militares, como a confirmar a leitura que Howard de Walden, embaixador inglês, fez dos acontecimentos. Costa Cabral, ao subir ao grão-mestrado e ao fomentar, ou, pelo menos, consentir a progressão maçónica no exército, ficou com um meio poderoso para influir nos negócios profanos. E para além de se saber se houve ou não um plano premeditado a comandar tudo isto, o certo é que, quando chegou o momento oportuno para se lançar à conquista do poder, a maçonaria funcionou como uma autêntica instituição política.

\section{A consolidação do poder}

O mesmo aconteceu na fase imediatamente seguinte. Cabral ter-se-á servido dos fundos do Grande Oriente Lusitano não só para subsidiar manifestações de regozijo público à Rainha, à Carta e à sua pessoa ( ${ }^{81}$ ), como terá utilizado a sua tesouraria para custear a publicação do novo órgão do cabralismo, o jornal A Restauração, e para financiar as campanhas eleitorais da sua facção ( $\left.{ }^{82}\right)$. Quer isto dizer que a maçonaria passou a servir

$\left.\mathbf{i}^{80}\right)$ Memórias do Marquez de Fronteira e d'Alorna...., Parte V e VI, p. 327.

(w) «E os fundos do G.I Tesouro, propriedade dos pobres e dos IIr.I necessitados, foram consumidos, com mãos pródigas, em objectos bem diferentes do seu destino! Se as músicas, se os fogos e os festejos que se viram, no dia 14 de Fevereiro, nas ruas por onde Suas Magestades passaram....; e os que se prepararam para a sua recepção no Teatro, aonde foram na noite do mesmo dia, e na de 11 do referido mês, assim como os que ao depois, em 1843 e 1845 se fizeram por ocasião do regresso das mesmas Augustas Pessoas à Capital, vindo das Províncias do Alentejo e Estremadura...., sendo tudo preparado pela Maçon.*, e levado a efeito à sua custa». $\mathbf{O}$ mesmo aconteceu com «as enormes despesas feitas com a célebre e histórica recepção pomposa do Ir.:. Fénelon, no dia 19 daquele mês» e «com a sustentação de um jornal político» (J. J. d'Almeida Moura Coutinho, ob. cit., pp. 79-80).

(") Segundo o Relatório de Contas e Orçamento Maçónico para o ano de 1844, o Grande Oriente Lusitano tinha gasto com o jornal $A$ Restauração a quantia de $1262 \$ 630$ réis, e com as eleições profanas 1138\$200. (Números transmitidos por Fausto de Quadros em nota à margem do seu exemplar da obra de M. Borges Graínha, História da Franco-Maçonaria em Portugal, p. 101, e depositado no A.U.C. VI-3.a_9.3). Para Moura Coutinho, o jornal causava ao Oriente um prejuízo de dois contos de réis por ano. 
de sustentáculo da nova ordem ( ${ }^{83}$ ). É que, conquistado o domínio sobre as instâncias superiores do estado, o novo ministro do Reino podia finalmente lançar-se na governação da sociedade portuguesa em nome de um pragmatismo político assente na burocracia estatal e numa oligarquia de pendor autoritarista $\left({ }^{84}\right)$. Para a concretização deste domínio, o Grande Oriente Lusitano continuava a ser-lhe útil, tanto mais que ao seu anti-setembrismo dava-lhe o estatuto de organização integrada no regime e necessária à sua defesa, possuindo, para isso, uma rede que ultrapassava, em muito, a duração clubista $\left({ }^{85}\right)$.

De facto, em 1843, contaria com mais de três dezenas de oficinas, número significativo ${ }^{86}$ ) num período em que a socia-

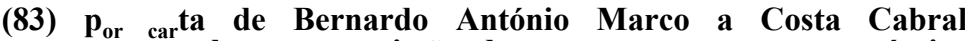
sabemos, por exemplo, que a missão de recrutamento para o exército atribuída ao coronel Rogado se devia à sua condição de mação. Cf. A.NiT.T., Arquivo da Família Costa Cabral. A II. Documentos Diversos, macete 72. Num documento da época redigido em francês, enuncia-se as razões do sucesso de Cabral e, para além de se apontar o seu carácter falso e intriguista, que o levou a grão-mestre, assinala-se que recrutou igualmente no exército e na igreja os seus apoiantes, ao mesmo tempo que procurou o suporte dos representantes da Santa Aliança e da Santa Sé. E para o controle do aparelho de estado apressou-se a favorecer com empregos públicos familiares e amigos. Cf. A.NiT.T., Arquivo da Família Costa Cabral A. C 12. Est. 198-204, macete 120.

$C^{84}$ ) Logicamente, a recuperação conservadora, reforçada com o golpe de Costa Cabral, repercutiu-se no trabalho das maçonarias rivais que terão sido perseguidas. Desde 1838, «grande número de seus membros foi vítima de perseguição e de exillio» (Manifesto dos II.-dissidentes da Maç.-. do Norte, ao Oriente de Lisboa, A.-. da V.*. L.-., 5844, p. 4).

(") Para além de grão-mestre do Grande Oriente Lusitano, António Bernardo da Costa Cabral ascendeu também, por regularização brasileira, ao lugar de Grande Comendador do Supremo Conselho do Grau 33, câmara do rito escocês. Esta regularização ter-se-á dado em 1841. Este Supremo Conselho funcionava em autonomia paralela junto do G.O.L. Cf. A. H. de Oliveira Marques, Figurinos Maçónicos Oitocentistas. Um "guia" de 1841-42, Lisboa, Editorial Estampa, 1983, p. 15, nt. 1.

(") As oficinas em funcionamento seriam as seguintes: Lisboa (União, 24 de Julho, Concórdia, 28 de Julho, Perseverança, Prudência, Filantropia, Marte l.a, Marte 2.a, Marte 3. ${ }^{a}, 27$ de Janeiro, Amizade, Marte 4.a, Constância); Porto (Legalidade, Restauração, União Portucalense). Contaria ainda com 7 lojas na província, 5 nas Ilhas e $3 \mathrm{em}$ Africa, perfazendo um total de 34 oficinas. Fonte: Miguel António Dias, Architectura Mystica do Rito Francez ou Moderno, p. 264. Como é natural, estes números têm um valor meramente indicativo, tanto mais que algumas lojas tiveram uma vida muito curta. Em termos ideológicos, não deixa de ser interessante notar, para além da existência de 4 oficinas militares, o aparecimento de outras que escolhecem para seu nome uma referência directa ao golpe de estado: (ex.: Restauração, 27 de Janeiro). Quanto aos seus 


\section{Revoltas e Revoluções}

bilidade política era fraca. No entanto, é natural que, para a consolidação do poder, desse agora prioridade ao controle e ao reforço do aparelho de estado, tanto mais que o cabralismo foi acentuando a sua tendência despótica e burocrática. O que, consequentemente, implicou uma secundarização da acção maçónica e uma valorização do funcionalismo público $\left({ }^{87}\right)$. Neste contexto, a atitude do grão-mestre face ao seu Oriente modificou-se e tornou-se ambígua: «nem queria a Maçon.*, vigorosa, para o não poder incomodar, quando lhe conviesse desprezá-la; nem se atrevia a abandoná-la de todo, com receio de que ainda não tivesse outro recurso, para a sua elevação ao poder, senão nos meios que ela pudesse prestar-lhe» $\left({ }^{88}\right)$.

Por tudo o que já ficou escrito, não surpreende que os efeitos da governação de Cabral e a sua gradual contestação tivessem dado força à corrente que, no seio do Grande Oriente Lusitano, não aceitava uma tão pessoalizada instrumentalização $\left({ }^{89}\right)$. Na opinião ainda de Moura Coutinho, o comprometimento das lojas no movimento restauracionista, se deu força à sua mais alta dignidade e ao trono, soou a muitos como o início da «ruína» (90) da Ordem, já que, uma vez consolidado o poder, Cabral deixou-a adormecer. Daí que o sector mais ritualista (Moura Coutinho, Conde da Cunha, Visconde de Oliveira, José Maria de Sousa Monteiro e outros)

efectivos, pouco ainda conseguimos apurar. Porém, sabemos que, em 1844, a loja Constância contava com 33 inscritos dos quais 25 se encontravam em actividade: a oficina Legalidade teria 27 activos em 37 inscritos e a União Portucalense 18 num quadro de 25 membros. Cf. A.U.C., Legado de Fausto de Quadros [Ficha de Lojas].

(8T) Naturalmente, a situação vitoriosa decorrente do golpe terá provocado o aumento da procura da iniciação maçónica no G.O.L., o que, para os mais ortodoxos e ritualistas, só poderia trazer consequências nefastas: "As admissões não foram, em regra, mais reguladas senão por considerações de conveniências políticas. Os aspirantes a empregos procuravam por todos os meios, e alcançavam com facilidade, a iniciação» (J. J. d'A. Moura Coutinho, ob. cit., p. 78).

(88) Idem, ibidem, p. 156.

(89) Em 23 de Novembro de 1844, ao responder, na Câmara dos Pares, à acusação de pedreiro-livre, terá tomado uma atitude pouco digna para os mações ortodoxos. Com efeito, o Conde de Taipa, na série de ataques que lançou ao governo, não deixou de invocar que o «Sr. Ministro do Reino.... era Grão-Mestre» da maçonaria. Cabral limitou-se a responder que «a respeito de todas essas acusações de maçonaria, juntava-as com as cascas de mexilhões pretos (de que ouvira falar noutra sessão), pegava nelas e deitava-as ao mar» (Diário do Governo, n. ${ }^{\circ}$ 280, 26-XI-1844, p. 1355, col. 2). Cf. também António Gregorio de Freitas, Memorias em Defesa da Maçonaria por um Maçon Portuguez fiel ao Rei e á Patria. 9.a Memmoria, Lisboa, Officina do Rito Escocez, Ao Oriente da Irlanda, 1861, p. 20.

(*o) José Joaquim d'Almeida Moura Coutinho, ob. cit., p. 75. 
começasse a movimentar-se para impedir a sua reeleição como grão-mestre em 1844. Mas, a eclosão da revolta de Torres Novas tê-los-á feito recuar $\left.{ }^{91}\right)$, pois concluíram que a derrota maçónica do ministro do Reino iria reforçar a oposição. Isto é, o fantasma setembrista funcionava, novamente, como um factor de solidificação da unidade conservadora, e mesmo os que não concordavam com os métodos políticos do cabralismo e com a sua liderança maçónica, perante o perigo, abdicavam da contestação a fim de fazerem frente à «coligação política» que atacava a ordem estabelecida. Deste modo, e sem grande resistência, António da Costa Cabral acabou por ser reeleito grão-mestre do Grande Oriente Lusitano em 1844.

Levar-nos-ia muito longe descrever o longo itinerário que levou ao exílio de Cabral - como consequência da Maria da Fonte e da Patuleia - , bem como analisar o seu regresso ao país, a sua nova subida ao poder e as razões que ditaram a sua demissão do lugar de grão-mestre a 1 de Maio de 1849. O mesmo aconteceria se pormenorizássemos os efeitos maçónicos destes acontecimentos e a eclosão de novos dissídios entre os cabralistas - liderados por João da Costa Cabral e António Pereira dos Reis (Washington e depois Ctesiphonio) - e a facção mais purista chefiada por Moura Coutinho, pugna esta que culminou na extinção do Grande Oriente Lusitano e no aparecimento da Grande Loja Portuguesa (92) (animada pelos primeiros, mas de fugaz duração) e do Grande Oriente de Portugal (93)

(91) Idem, ibidem.

(92) Esta maçonaria teve como seu grão-mestre Francisco Castelo-Branco ( Cang anelli).

(93) A instalação do Grande Oriente de Portugal deu-se em Julho de 1849. Cf. A.U.C. Legado de Fausto de Quadros. [Actas da Constituição do Grande Oriente de Portugal], fis. 1 e ss. Para os seus corpos superiores foram eleitas as seguintes individualidades: grão-mestre, Visconde de Oliveira (Fábio); grande inspector geral, José Joaquim d'Almeida Moura Coutinho (Licurgo); grande conservador, Conde da Cunha (Antenor,); grande 1. ${ }^{\circ}$ vigilante, José Joaquim Alves (Plutarco); grande 2. ${ }^{\circ}$ vigilante, Manuel Freire de Faria (Ferreira); grande orador, José Maria de Sousa Monteiro (Scipião Africano); grande secretário, José Lucas Cordeiro (Othon); grande $1 .^{\circ}$ experto, Luis José de Sampaio (Aquiles); grande 2..$^{\circ}$ experto, António de Sousa Cirne (Haníbal); grande $3 .^{\circ}$ experto, Tomás Oom (Alexandre); grande $4 .^{\circ}$ experto, Mateus Valente do Couto (Pedro Nunes); grande tesoureiro, Francisco da Silva Carvalho (Camões); grande chanceler, João de Vilanova de Vasconcelos Correia de Barros (César); grande mestre de cerimónias, António Jacinto de Sousa Gomes (Leovogildo) ; grande arquitecto decorador, Frederico Lourenço Pais de Sousa (Radtezky); grande solicitador geral, António Augusto Pereira da Silva (Fenelon). Cf. A.U.C., Legado de Fausto de Quadros. [Acta da tomada de posse das altas dignidades do Grande Oriente de Portugal], fis. 61 e ss. tem a data 
(que teve em José Joaquim d'Almeida Moura Coutinho a sua figura mais activa). Para se abarcar tudo isto, ter-se-iam ainda de estudar as paulatinas alterações operadas nas relações entre a maçonaria e a política e que conduzirão ao aparecimento, por um lado, de um novo Grande Oriente Lusitano (nascido do seio do Grande Oriente de Portugal) e, por outro, ao crescimento das tendências unificadoras, em clara sintonia com o clima consensual que a Regeneração ${ }^{94}$ ) procurou consolidar. Porém, este quadro ficaria incompleto se não se tivesse também presente a outra face da realidade maçónica, isto é, se não se descrevesse a actuação das maçonarias mais radicais e o seu caminhar numa direcção mais moderada até à sua confluência com a maçonaria cartista, percurso este que ficou consubstanciado na fundação do Grande Oriente Lusitano Unido (1869). Por último, seria igualmente útil e necessário saber algo de seguro acerca do posicionamento social do povo maçónico $\left({ }^{95}\right)$ e respectiva evolução.

Como se vê, seguir todas estas vias e articulá-las com as mutações sociopolíticas implicaria uma interminável rede de pesquisas que está longe de ser feita. Por isso, só podemos terminar este trabalho com uma ilação genérica, mas de um valor provisório, que urge completar com outras investigações: se, na primeira fase do liberalismo, as maçonarias actuaram como clubes políticos, ou mesmo como proto-partidos - como aqui se procurou mostrar -, a consolidação do regime cons-

de 19 de Julho de 1849. Veja-se também Acto Constitucional da Franc-Maçonaria Portugueza dado e sancionado aos 27 dias do mez de Thamouz do an.' da V.| Lr. 5849 (era vulgar 17 de Julho de 1849) pela Gr.I Dieta Geral Constituida e Constituinte da Maçon.'. Luzitana convocada extraordinariamente por decreto da Gr.। Lr. do Grr. Orr. Luzit.'. de 18 de Maio de 1849, Lisboa, Typographia do Gr.। Or.*, de Portugal, 1849.

(M) Isto é, impor-se-ia a necessidade de se investigar a validade da asserção já formulada pelo católico Conde de Samodães em 1873: a Regeneração teve «notável influência na maçonaria que perdeu o carácter exclusivamente pessoal que tivera nos anos anteriores», sofrendo, assim, uma transformação em sintonia com «que afectou os partidos politicos, em que se dividiu o grupo militante do país, e passou a funcionar com membros de todos eles» (Conde de Samodães, «Proemio do Tradutor", in Padre Francisco Xavier Gaudelet, $A$ Franc-Maçonaria e a Revolução, Porto-Braga, Livraria Internacional, 1873, p XLIV.

(i) Conquanto só um levantamento sociológico da população maçónica nos possa esclarecer acerca do posicionamento social dos seus membros, a biografia de alguns maçons do G.O.L. que conseguimos identificar indica-nos que as suas figuras mais influentes pertencia ao alto funcionalismo público: oficiais do exército, magistrados e alguma nobreza liberal (Conde da Cunha, Visconde de Oliveira). 


\section{A Maçonaria e a Restauração}

titucional e a emergência de correntes políticas melhor organizadas permitiu-lhes alcançar, gradualmente, uma prática confinada às suas tarefas próprias e, em relação à sociedade profana, aos limites variáveis de um grupo de pressão. E se esta última característica começou a acentuar-se com a Regeneração, não será descabido dizer-se que se sublinhou ainda mais nas décadas seguintes. E será necessário aparecer um outro momento de profunda crise social e política para se assistir a um novo assomo de sobrepolitização da maçonaria, então condicionado pelo projecto de liquidação da monarquia e da influência do clero. Referimo-nos, logicamente, à evolução finissecular que desaguou na republicanização do Grande Oriente Lusitano Unido e no seu consequente funcionamento como instituição ideológica integrada na estratégia do Partido Republicano. Em suma: foram complexas e muitas vezes antagónicas as relações entre as maçonarias e entre estas e a política. E só um estudo aprofundado de todas as suas implicações nos poderá dar um conhecimento objectivo capaz de afastar, de vez, os preconceitos e as ideias feitas. 